\title{
Race and racism in South American archaeology
}

\author{
Rafael P. Curtoni and Gustavo G. Politis
}

\begin{abstract}
This article addresses the issue of race and racism in the archaeology of South America taking into account contemporary contributions in order to analyse and discuss the subtle functioning of racist thinking and ideas. It also provides a theoretical framework of departure for deconstructing and interpreting race and racism as social and cultural phenomena trying to elucidate the powerful effects implied by racist feelings. In a more general sense, this paper attempts to show that race and racism are still vivid in many social and cultural fields - including scientific and academic ones, functioning sometimes as a powerfully rooted belief.
\end{abstract}

\section{Keywords}

Racism; archaeology; South America; social contexts; cultural racism.

\section{Introduction}

Race and racism, as culture, are difficult concepts to define simply in the social sphere, and even more regarding their relationship with the past when recovered by archaeology. Therefore, the issue of race and racism and their relationship with archaeology has barely been considered or explicitly analysed in South America. The aim of this paper is to analyse the phenomenon of race and racism, and its expression in the archaeological enterprise developed in the region since the beginning of archaeology as a science. In order to accomplish this goal we will examine some contemporary South American examples and try to grasp subsumed or explicit ideas related to race and racism that have been used to sustain archaeological interpretations.

This paper develops a short theoretical discussion of concepts showing the historical setting of race and racism, in order to provide a spatial and temporal context for the issue. Furthermore, some contemporary South American cases are presented to portray the uses of race in archaeology, and for deconstructing the meanings and connotations of that 
relationship. The current presence and reification of the concepts implied in politics, history, geography and anthropology regarding the social construction of race will be also examined.

\section{Interpreting race and racism}

It is generally agreed that the concept of race emerged in several European languages just around the time when European colonialism and imperialism were encountering people in other countries and categorizing them into some form for domination. Race and racial thinking have been used continuously to justify and legitimate white supremacy, exploitation and social inequality (Stocking 1968; Young 1996; Wade 2004). In a similar vein, the concept of racism arises as a phenomenon biologically centred and naturally associated with the socio-economic organization established in Europe at the beginning of the eighteenth century (Archenti et al. 1993). At that time, race and racism were rooted in biology in order to classify human variation into a discrete number of definite categories, each of them having a set of common features, such as skin colour, hair type, blood group and so on. Even today, some scientists still use those concepts in this biological way, and believe that race is still useful as an analytic category to describe human genetic variation (see critics in Wade 2004: 158). Likewise, during the nineteenth and twentieth centuries the concept of race was also linked not only with biological features, such as skin colour and facial traits, but also in terms of moral and intellectual attributes. Even more, this idea was akin to the controversial theory that intelligence and some social behaviours could be related to a certain type of race, considering it as a real biological entity (Dawkins 1985; Grillo 2003). These ideas of race and racism have been scientifically supported from sociobiology, promoting greatly heated debates in the social sciences, because discrimination and human differences were sustained in respect of some biological attributes. As was pointed out, racism 'was grounded in biological essentialism and determinism, the idea that human beings could be placed in groups based on physical characteristics, or more deeply, their genetic make-up' (Grillo 2003: 162). This theory, entitled 'scientific racism', held that human beings could be divided into a small number of exclusive races that had a particular essential nature which established the differences among them. At present, this biological construction determines the natural divisions among humans, reflected in four categories that have been identified as Mongoloid (north-eastern Asia), Australoid (Australia and Southeast Asia), Caucasoid (western Asia, Europe and northern Africa) and Negroid or African (sub-Saharan Africa). Moreover, some scientists have been trying to define such races 'and prove that the white or Caucasian race had the biggest - and hence the best - brains' (Wade 2004: 160). This conception of race and racism has been criticized by different scientists arguing that no set of biological characteristics could be isolated to allow division among humans (Gann 2000; Grillo 2003).

Racism is also closely linked with ethnocentrism, a concept that was defined as 'the manner in which a group identifies with its own socio-cultural individuality and creates a privileged and central image of itself in relation to others' (Shanks and Tilley 1987: 155). This attitude, in one way or another, seems to be universal among societies, including indigenous groups, many of which regarded themselves as having a privileged and superior 
position compared with other people. Classic examples are the Kogi of the Sierra Nevada de Santa Marta in Colombia who consider themselves as the 'guardians of the world'. The assumption made by almost every ethnic group in the world is that they are the 'true people', the 'chosen people' or the 'first people', which seems to be a basic principle and inherent in the construction of ethnic identity (see discussion in Hernando 2004). However, in Western society and closely linked with racism, ethnocentrism is also another tool to promote or justify the colonization, domination and exploitation of the subordinated groups (Gosden 2001; Shepherd 2003). Its use in archaeology has obliterated a proper understanding of past societies and has misled archaeological inquiry. Basically, the derivation of this attitude has produced a projection of modern capitalist society into the past societies' value systems. This can be seen among the many examples of parallels drawn from contemporary capitalist value systems, such as maximizing return and minimizing costs to explain the resource utilization among past foragers (Shanks and Tilley 1987: 188).

A currently different theory about race holds that races and racism are social constructions functioning as an idea, which has no biological basis, to be used in justifying and sustaining human discrimination. Considering racism as a socially constructed phenomenon implies regarding it as a part of a system of domination based on relations of power and prejudice, and intimately connected to colonialism and imperialism (Young 1996; Wade 2004). Consequently, to understand racism properly, it is necessary to situate its expressions within the wider social structure of class difference and exclusion, which in some cases support and legitimate it (Gann 2000). Furthermore, this theory also recognizes that race has become deeply embedded in Western ways of thinking, and that considering it as a social construction does not 'prevent race being a very important and often deeply rooted notion that affects people's behaviour and life chances in significant ways' (Wade 2004: 159). For example, the systematic mistreatment of black people in USA and South Africa is the outcome of institutionalized inequalities in the social structure. In that way, racism arises as a result of an enduring idea that consistently benefits some members of ethnic and cultural groups in opposition to others, therefore having consequences at the economic, political and social level.

In Europe during the 1980s, scientists detected a so-called 'new', 'cultural' racism, the name given to the enunciation of difference based on cultural grounds and cultural essentialism (Gann 2000; Grillo 2003). This new form of racism operates in a subtle manner and is conceived as classical racism in disguise, emphasizing differences of cultural heritage, traditions, and assuming the distinctiveness of some group, reifying their cultural boundaries and incommensurability (Grillo 2003). This shift from racism based on biological traits to theories of cultural racism is closely bound up with the rising and construction of nation, nationalism and ethnic identities. Sometimes this kind of racism has become cultural fundamentalism, spatially segregating cultures that cannot and must not communicate or mix with one another, as is sustained when the 'thesis of inassimilability of non-European immigrants and the racialist overlapping of biological and cultural arguments are used to promote respect for differences' (Taguieff 1990, in Grillo 2003: 164). In some cases, this call for the right to be different is strongly related to the growth of contemporary xenophobia that can promote doctrines of cultural exclusion, nationalist movements and ethnic politics. To the same extent, Fascism, Nazism and 
South African apartheid resulted from an idea (of the nation, ethnic group or race) and from ideologies associated with that idea (nationalism, racism) (Kellas 1998).

On the other hand, xenophobia can also be visualized through the political manipulation of the past; being useful in order to achieve and promote the glories and national pride of ethnic groups possessing or having some relationship with power. There are many examples of this kind, ranging from Franco's Spain, Hitler's Germany and Salazar's Portugal to Stalin's Soviet Union (Arnold 1990; Díaz-Andreu 1993; Kohl and Fawcett 1995; Oliveira and Oliveira Jorge 1995). At the same time, within every country, different ethno-national ideologies have emerged looking for self-identities, taking unto themselves certain kinds of superiority based on race relations. In these cases, the archaeological research, language of publication and management, and conservation of sites are influenced by different interests of these ethnic groups, such as ideas of nationalism and cultural racism. In other cases, the present is linked to a particular past or 'golden age' and emotional power is invested in archaeological sites considered as symbols of national pride, such as Masada in Israel or the classical cities like Paphos, Kition and Ammathus in Cyprus (Silberman 1995). In South America the cases of Tiawanaku in Bolivia or Machu Pichu in Perú are also examples of the current use of archaeological sites as symbols of national pride and as material derivatives of a glorious past (see, for example, Mamani Condori 1996; Millones 2004; Angelo 2005).

\section{Racism in the emergence of the nationalities in South America}

The new colonial scenario established with the discovery of America in the fifteenth century defined a modern pattern of world power in which the codification of difference between conquerors and conquered was based on the idea of race in order to justify and legitimate the social relationships of dominion (Quijano 2003). The expansion of European colonialism throughout the world promoted the construction of a Eurocentric perspective on knowledge and tied with it the theoretical elaboration of the idea of race as naturalization of colonial relationships of dominion, exploitation and social difference (Lander 2003). This colonial and racist Eurocentric thinking permeates social science in general and archaeology in particular, and was present at the beginning of archaeological research in South America, which was mainly in the hands of foreign investigators (Politis 1995; Langebaek 2003).

At present, South America comprises fifteen countries, forming the fourth largest continent in the world. With the exception of the three Guyanas and a few Caribbean islands (Netherlands Antilles and Trinidad and Tobago), all the other countries share a Spanish-Portuguese background and a strong Catholic tradition. These countries are former Spanish and Portuguese colonies, which became independent in the early decades of the nineteenth century after several years of war. Although the majority of the population is of European descent in countries such as Argentina, Uruguay and Brazil, in other countries, such as Perú, Bolivia and Ecuador, indigenous or mestizo population dominates. As with Latin America (see discussion in Politis 2003), the term South America has little utility in defining or characterizing a type of archaeology performed in the region. Indeed, there are a variety of sub-regional and national traditions of archaeological 
practice, with significant differences between them. Therefore, in this paper the references to South America as a spatial unit of analysis are functional and by no means signify a unified body of theory, method or technical approach.

In many South American countries, intellectuals and politicians related to power have carried out the construction of nationality, based upon imagining a society fashioned mainly by white classes with a European background. In that project indigenous people and minority groups were considered as barbaric, inferior and without 'civilization'. Thus, there were only two ways of encompassing the Indian issue: they should be exterminated or integrated and hence Christianized and civilized. For instance, through the process of consolidating the idea of nation in Colombia, in 1861 Jose Maria Samper, intellectual, politician and military man, proposed a racial pyramid to arrange and establish the ethnic diversity of the country. The white race was located at the peak of the pyramid; the mestizos were placed in the middle level and at the bottom the indigenous people. In the first half of the twenty century, Luis Lopez de Mesa, intellectual of the Liberal Party, postulated the integration and mixing of the Indian with superior races such as whites, through a process of what has been called of 'whitening'. Regarding the condition of the indigenous people, he stated that they are 'from a class of weak animals reloaded with human malicious' (see Moreno Sandoval 1998). This racist thinking, and also the neglect of the prehispanic past, has fashioned some of the bases for defining and establishing the Colombian nationality and identity, mirroring the European states.

An interesting example of racist thinking is found in the ideas of Colombian Carlos Cuervo who proposed a racial division for South American Indians: the pampeana race, the most primitive; the andina race, the most developed which had its origins on the border of the Titicaca Lake; and the most recent the Caribbean race. Cuervo recognized that these three Indian 'races' represented groups which belong to the pampeana race, living today in the Amazon. Cuervo's ideas defined and established a strong relationship between race, culture and the potential for cultural development: not all the races had the same abilities to achieve a higher level of complexity (see discussion in Langebaek 2003).

Similarly, the constructions of nationalism in Chile were schematized by the intellectual and historian Nicolás Palacios, through his book Raza Chilena (Chilean race) published in 1918. Palacios imagined an ideal society with European pretensions and established a myth of origin for Chilean people in the mixing of whites (belonging to the Germanic race) and the native indigenous people known as araucanos, forming a new race called araucoGermanic. This new race characterizes a way of being Chilean, having different and hence high intellectual psychological and physical traits. This powerful discourse permeated the further construction of the national identity, and in some ways contemporary historical narratives (see Borgoño 2004).

In other countries of South America, this situation had the same characteristics. Dominant classes used the idea of race, anchored in a poor understanding of Darwinian ideas, in order to justify the genocide of many indigenous groups and to legitimate the population replacement of local Indians by white Europeans (Podgorny and Politis 1992; Ramos 1997; Funari 1999; Langebaek 2003). Evolutionism and racism provided the conceptual framework for the construction of national identity, where the white European had to provide racial elements to improve or replace indigenous races. This replacement was seen as a necessary condition for developing the countries, since Indian races did not 
have the capacity needed and imagined for that enterprise. For instance, the history of Indian-white relations in Brazil has been regarded as manifested in two dominant and parallel notions of the Indians. They were depicted, on the one hand, through a rhetoric of the noble savage to be preserved and, on the other, as inferiors to be civilized by white superiority, 'whose moral responsibility was to rescue the Indian from barbarism' (Ramos 1997: 74). Elsewhere, racism against Indian mestizos and black populations was frequent and explicit in writing, speech and actions.

With the spread of diffusionism in the first decade of the nineteenth century (Trigger 1989), archaeology changed the focus of research, but the concept of race was still more than alive. In South America, culture-historical synthesis of regions and areas became the main objective, involving a direct historical approach. In this context, diffusion emerged as a key concept, and the racial approach to studying the human skeleton was seen as one of the best tools for understanding the pattern and history of diffusion (Politis 1995). Among many examples, the racial model proposed by the Italian physical anthropologist José Imbelloni (1937, 1938, 1942) was particularly influential because he identified several American racial groups, and traced them through time and space. As was common in those times, some contemporary indigenous groups were seen as living representatives of ancient races.

\section{Racism against the Indians}

The spread of the Indigenismo ${ }^{1}$ movement in South America in the 1930s, along with new ideas and concepts that gained entry into archaeology during the middle of the twentieth century, slowly eroded the foundation of racial thinking, and diminished racist ideas in the discipline. However, some anachronistic positions still survived amazingly prominently as late as the 1960s. Perhaps, the most flagrant case is that of Milciades Alejo Vignati, an Argentinean archaeologist who was a professor and researcher at the Museo de La Plata (Universidad Nacional de La Plata) for several decades in the twentieth century. Vignati developed a prolific career focused in archaeology and ethnography of the pampean and patagonian region of Argentina (Vignati 1931, 1953, 1957-59). He was a well-known and prestigious professor who influenced the education of many Argentinean archaeologists. In his latest writings Vignati displayed his racist view of the aboriginal people from Argentina; a view which permeated his research in one way or another. In an article published in the 1960s about archaeology in the province of Buenos Aires, Vignati discussed the high degree of 'mestizaje' of the very few Indians (basically Mapuches), who were living in the wealthiest region of Argentina, concluding that '[t]ruly, the Indians exist no more in the province of Buenos Aires' (Vignati 1960: 99). However, in the final paragraph of the article Vignati warned about the potential danger of a new indigenous immigration into the province, and by doing this he sharply revealed his negative feelings against the Indian people:

Buenos Aires province, like the provinces bordering it to the North, could proudly show its racial census clean of any indigenous defect. The province has another danger and it has to offer resistance to it with all its legal strength in order to avoid surrendering to the degeneration of its race. Five years ago, a group from the Chaco 
area, which in their times received an appropriate and depressing name, has invaded ${ }^{2}$ Buenos Aires. It is necessary to make them go back to their place if we do not want the number of coloured people to occupy important places in the census. This would constitute shame to the province which was not so long ago free from this weed.

(Vignati 1960: 132)

There are two amazing points in this example. The first one is that the article was, even at that moment, certainly out of its epoch. Vignati's racist ideas were anachronistic at that time, and not only in the discipline, for society in general had already overcome these ideas, more akin to the ideology of the end of the nineteenth century. The second point is that the article was published in the Anales de la Comisión Cientifica de la Pcia. de Buenos Aires, the official scientific institution of the main province of Argentina, when the governor was Oscar Alende and the president of the country was Arturo Frondizi. Both had been democratically elected and represented a period of freedom and expansion of social sciences in the country, contrary to the previous and subsequent military governments. Actually, during the presidency of Frondizi, the first careers in anthropology (and archaeology as a speciality) in the two main universities of Argentina were open (see Politis 1992).

It remains to be known if Vignati could 'slide' his article in this journal due to personal and political connections (which would mean, without any serious scientific review and any ethical consideration of the content) or if the ideas expressed by Vignati were shared by an important segment of the scientific community which tolerated them. However, it is important to note that there was not even one public (oral or written) reaction against Vignati's anachronistic view of the Indians in Argentina. Vignati's uses of racism can be considered as an expression of a racism that is a socially constructed phenomenon based on biological attributes and related to a political system of domination, power, social prejudice and class difference.

\section{Cultural racism}

This subtle and possibly unintentional way of racist thinking is quite evident in the history of archaeology in South America. It is easy to trace a clear opposition between two areas and two hierarchies of indigenous society. Archaeology during the whole twentieth century was dominated by the dichotomy: central versus marginal areas. In the first area, basically the Central Andes, main cultural innovation occurred when social and economic complexity reached its peak: true 'civilization' was developed. The second area was peripheral, the southern Andes, tropical lowlands, Chaco, pampas and patagonia, etc., where very little happened; innovation and invention occurred elsewhere, and economic and social complexity remained low and dull. Julian Steward's (1949) masterpiece The Handbook of South American Indians clearly reflects this view although based more in ethnography than in archaeology. The other dichotomy was between simple or 'inferior' types of societies (such as the 'cazadores-recolectores inferiores', inferior hunter-gatherers) and more developed groups, those from the Andes who reached the status of 'superiors'. Needless to say, one can expect great achievements from the more 'civilized' societies, and 
very little from the 'marginal tribes' (sensu Steward 1949). The technological and material culture of the marginal people was rudimentary and 'generally lacked the developed agriculture, building arts, and manufacturing processes found among other South American Indians' (Steward 1949: 672). On the contrary, the central Andean people ('civilized') had the most developed agriculture systems, the densest population, most efficient transportation, true urban centres, metallurgy: 'excellence of its products, and finer goods were produced by special craftsmen for the upper classes' (Steward 1949: 674). This form of organizing archaeological material culture followed, used as late as the 1960s and 1970s. In a similar vein, Gordon Willey defined nine archaeological culture areas in South America, regarding technological advances, subsistence economy and the natural setting occupied and exploited. As in Steward's case, Willey established the Peruvian or central Andean area as derived from the Peruvian cultural tradition (based mainly on intensive agriculture), as the 'area of the foremost South American native civilisation' (see Willey 1971: 22). As was stated before, these cases portray subsumed racist feelings that can be rendered as forms of cultural racism possibly unintentionally achieved.

In the Southern Cone, the work of Enrique Palavecino represents a good example of several dimensions of cultural racism. Palavecino was an ethnographer who also did some archaeological and linguistic studies. His main contribution was ethnographic research in the Chaco region, and in several of his books and papers he defined and characterized the cultural areas of Argentina and South America. In a paper originally published in 1948 (then reprinted in 1977), Palavecino defined different cultural areas of the Argentinean territory based mainly on ethnographic and archaeological data. His paper constituted a seminal work for archaeologists for many years, not only because some areas are still today conceived in a similar way, but also because many archaeologists reproduced the perspective of Palavecino. Considering cultural development and economic way of life, the author defined different types of cultures representing diverse evolutionary trajectories. In this way, fishermen located at the south of the Pacific Ocean in Chile and Argentina, the pampean and patagonian guanaco hunters and foragers of the Chaco area were all regarded as 'protocultures'. This means they were considered to be an 'inferior stage', characterized by a nomadic way of life, socially organized in small bands with simple technology, and without having agriculture and pottery production. The inhabitants of the Lowlands Tropical Forest from Argentina and Brazil have been considered as 'inferior agriculturists'. Their social organization was considered to be at the tribal level, having small houses that grouped to form little towns; their economy was based mainly on farming activities (using clearings in the forest), and also on fishing and hunting; technologies such as pottery production and basketry were also developed. Finally the Andean cultures were viewed as 'high' cultures, being the centre of cultural production and innovations, demographically populated, and with great technological development (Palavecino 1977 [1948]). The other significant point is that for Palavecino this cultural hierarchy had strong implications for the present. In a more recent paper (Palavecino 1965), he proposed that the main problem for the integration of current population in the Chaco area was due to its level of social evolution.

The catastrophic situation of the indigenous groups from Chaco comes from the historical differences between the aborigine culture of a miolitic level, which was 
reached by human kind 40,000 years ago, and the industrial civilization, which is quickly coming into the Chaco region... within a couple of generations they [the aborigines] must acquire the notion of nationality, citizenship, moral law, etc.

(Palavecino 1965, in Califano et al. 1985: 58)

This particular division shows a case of cultural racism in which the superiority of one group has been seen with regard to cultural traits, heritage, economic development, and also been considered spatially segregated. Different professionals throughout Argentina have adopted these divisions between cultural areas and the archaeological features that generally and hypothetically must have been associated with them, and this still permeates the practice of archaeology.

The prehistoric past of Uruguay is quite informative about the role played by racist ideas in the process of creating an image of the prehispanic Indians. The traditional models integrated the archaeological record of Uruguay to a regional model of cultural development within the macro-region pampa-patagonia (i.e. González 1953; Schmitz 1976; Taddei 1981). These models reinforced the influence of the pampean and patagonian hunter-gatherers, and diminished the monumentality of earth mounds locally known as 'Cerritos de Indios' (see discussion in López Mazz 2004). However, the long-term project in the Laguna Merin Basin has revealed clear indications of early domestication of some plants and an emerging cultural complexity since c. 3000 BP (Gianotti 2000; Iriarte et al. 2001; López Mazz 2004). While Uruguayan archaeologists are currently debating the foundations and implications of that model, new archaeological scenarios have provoked a virulent reaction by some historians and anthropologists. Among their reactions, some are absolutely astonishing (see summary in López Mazz 2004). For example, historian Vidart said 'the excavations have uncovered just a pre-Hispanic dog skeleton, but not a pumpkin seed or any other minimal detail to make a different panorama from what had been discovered through all these years of excavations' (Vidart 1996: 6). In the same vein, José de Torre Wilson, the director of the Museo Histórico Nacional declared:

although many Cerritos and other sites have been excavated, not a single complete skeleton, a single city, a single house, a single temple, a single wall, nor agriculture or any residue of metal has been found in the whole Uruguayan territory. Only sporadic campsites which appear sporadically.... It is known that there were human beings 10,000 years ago ... but to try to put these civilizations at the level - not of the Mayans or the Aztecs - but of the guaranies is a serious mistake.

(Torre Wilson 1996: 22)

Anthropologist Renzo Pi Ugarte, who in his classic and relatively new book about the Indians of Uruguay, casts doubts on whether new archaeological information, which suggests a certain degree of complexity in the Cerritos, had returned to the old model. $\mathrm{He}$ provides a third example proposing that the Indians were basically 'superior huntergatherers with patagonian links' and that the Cerritos were simple constructions for living during the seasonal flooding (Pi Ugarte 1993: 94).

The whole discussion indicates again that racist thinking is still vivid in significant segments of many academic communities in South America. The case here shows that 
some scientists seem to feel more comfortable with the old idea of pre-Hispanic, 'uncivilized' Indians, rather than with a new idea which displays Indians building monumental earth mounds, domesticating plants and embarking on a process of social complexity. The old model is more akin to the construction of national identity, where the Indians were brutish and fierce, without any trace of civilization. Therefore, their extermination was compulsory due to their ferocity (see discussion in Verdecio 1996). The old model was functional for the colonial and neo-colonial order, while the new one highlights the immoral extermination of Indian people in Uruguay.

A similar case has emerged recently in one of the main Argentinean newspapers, in which the president of the Argentinean Academy of History, professor Juan José Cresto, expressed an idea about indigenous people, which can be regarded as falling into some form of cultural racism (Cresto 2004). Cresto denies the existence of indigenous people in the Argentinean territory of pampa and patagonia, explaining that the region was occupied by Araucanos from Chile during the beginning of the eighteenth century, and colonized by the colonial Spanish expeditions of the sixteenth century. In this way from a historical discourse, the region was considered a desert or uninhabited place in order to legitimate its occupation by white settlers, which was referred to as 'conquest of the desert'. This violent invasion and extermination of indigenous people from the pampas and patagonia was carried out between 1879 and 1884, and a national narrative promoted around the campaign of the desert made sense of the war against the Indians as an historical and inevitable necessity (discussion in Curtoni et al. 2003). The systematic neglect of indigenous existence attempts to remake that history, at least in Argentina, by beginning with the first arrival of Spanish civilization, and asserting that the few and spatially concentrated indigenous people living there took advantage of the inventions, discoveries, technologies and new animals introduced by whites. This case clearly illustrates the intentional construction of a national project promoted by political and intellectual groups belonging mainly to an upper class and with European pretensions. The national identity had been formed considering the Indians as barbaric, without civilization and history, and therefore their extermination was viewed as natural. Thus racist thinking and cultural racism are at present permeating the academic field in an explicit way to maintain discriminatory attitudes against indigenous people in favour of a more developed white civilization. Archaeologically, it can be maintained that the contemporary development and official support for researching forts and places related exclusively to historical white settlements may reveal the subtle permeating and enduring racist ideas powerfully rooted in the construction of history and national identity.

As has been pointed out by Gnecco (2002), the national construction of the state, and hence national identity in Colombia, was based on constructing and imagining a present history and projecting it into the past (Gnecco 2002). From the beginning, that projection confronted indigenous and black (past) identities with modern identity. As a historical process, the emergence of national identity was based on considering the past as traditional, backward and heavily black and Indian (Wade 1997: 64). In that case, diffusionism legitimates the process of civilization (materialized through the conquest and extermination of indigenous people), making it natural and establishing a historical continuity between the progressive diffusionist events of the past and those from the present. On the other hand, the prehispanic groups with more cultural 'achievement' have 
been erased from history by way of catastrophic events (in which people have disappeared), and have been replaced by cultures more 'underdeveloped'. The vanishing of prehispanic societies has been a recurrent issue in archaeological and historical narratives of Colombia (Gnecco 2002: 136), and similar reasoning has been reported in other South American countries such as Chile, Bolivia, Brazil and Peru (Funari 1995; Borgoño 2004; Millones 2004; Angelo 2005). In Colombia, contemporary indigenous people were, and still are, shown in their origin as cases of 'population discontinuity'. They cannot be shown to be and legitimized as descendants of those prehispanic people having a 'high' cultural development. For example, the prehispanic San Agustin culture, in which high-quality statues were elaborated, has been reported by some archaeologists as 'vanished' from the Amazon, or has been replaced by other indigenous groups. In this way, contemporary indigenous people living in San Agustin valley were also considered to have no cultural connection with the prehispanic past (Gnecco 2002; Gnecco and Hernández 2005). The disconnection of cultural continuity served to de-legitimate possible contemporary territorial claims and to characterize present indigenous conditions as products of their own underdeveloped culture. It is clear from the above example that racist reasoning was strongly embedded in the project of national identity, and permeates perhaps unconsciously the way of thinking and being at that time.

\section{Concluding remarks}

As explained at the beginning of this paper, it seems clear that race and racism are socially defined phenomena, implying therefore that there are no biological grounds to sustain or legitimate discrimination among human beings. However, there are still many social and cultural domains - including some scientific and academic ones - strongly rooted in the belief that racism has some meaningful base in human nature, even beyond the superficial aspects of skin colour and hair texture (Wade 2004). This powerful belief might be found in subtle ways and subliminal types of racism, such as contemporary cultural racism, and also in 'common sense', which is difficult to identify, isolate and challenge.

As mentioned earlier in the text, many of the South American cases fall into various forms of cultural racism, demonstrating that racist ways of thinking still permeate a diversity of social, political and intellectual spheres. Archaeology and the construction of past narratives are no exception. Archaeologists must be aware of the danger in using contemporary categories and concepts uncritically, with subsumed implications related to thoughts and ideas derived and imposed from political and economical orders, such as colonialism and imperialism. In a similar vein, the reification of cultural differences can promote the segregation of particular human groups, generating xenophobia and social exclusion. Academic doctrines, such as diffusionism tied together with ethnocentric and neo-colonial scenarios, provide and constitute efficient contexts to originate and promote opinions and values related to racist feelings, legitimating, among other things, cultural discrimination and political domination. For instance, as mentioned earlier, different attempts have been made in South American archaeology to document historical discontinuity between prehispanic societies (considered 'high' cultures) and contemporary native people (considered 'underdeveloped cultures'), trying to dismiss any possible 
connection among them. At first glance, it would seem that racism holds an omnipresent status, permeating all the subterfuges of human reasoning and thinking, considering racism as a basic and unavoidable idea that is later naturalized in existence. What is naturalized is not racism per se as a concept, because it has been politely and politically vanished, but rather the implications of the idea that are acting and affecting different social, cultural and political settings. Thus, racialized ideas posited in scientific discourse seem to operate by hiding political interests, power relationships and cultural discrimination, delegitimating and neglecting present-day indigenous claims and rights. A possible way to identify and subvert racist thinking is to situate archaeological research in postcolonial perspectives trying to deconstruct the ideas of globalization and naturalization that constitute modern neoliberal society. Moreover, a symmetrical dialogue between archaeologists, indigenous, mestizos, blacks and other subordinated people would de-colonize archaeological practice (Zimmerman 2000), therefore helping to remove the racist elements still present in current thinking. The contradictory essence of concentrating on analysis of racism as operating only in subtle manner, and disguised through different notions, reinforces the powerful effects implied in the idea beyond the discussion of concepts. Therefore, not only must we be alert to the use of conceptual tricks in thinking and constructing racist feelings and ideas, but we should not allow or facilitate the development of contexts (e.g. neo-colonial, scientific, academics or social) in which those effects can be achieved.

\section{Acknowledgements}

Thanks to Maria Luz Endere for some bibliographical references and to the anonymous referees for their comments and observations. Also thanks to Daniel Rafuse for correcting the English. Needless to say, the ideas developed in the article are our entire responsibility.

Rafael Pedro Curtoni, Universidad Nacional del Centro de la Provincia de Buenos Aires. Gustavo G. Politis, National Research Council of Argentina, Universidad Nacional del Centro de la Provincia de Buenos Aires and Universidad Nacional de La Plata, Argentina.

\section{Notes}

1 The origin of the Indigenismo movement is inextricably related to the first European attempts to subjugate indigenous people of the American continent. During the 1920s Indigenismo was performed as a political protest against the exploitations and injustices that Indians continually suffered. Some popular political parties were in tune with the Indian claims, and also made political use of the issue. Indigenismo flourished during the 1930s, mainly in countries such as Mexico and Peru, and later extended its influence throughout the South American continent. With the consolidation of modern nationstates, Indigenismo seeks to integrate indigenous people into national society, with regard to their particular values and customs. Although the Indigenismo movement 
helped to introduce the Indian issue into the national agenda, it sometimes retained aspects of paternalism, constructing essentialist images and master narratives that tended to marginalize those it pretended to help (Barre 1983; Alcina Franch 1990; Ramos 1997; Lazzari 2002; Gnecco 2002).

$2 \mathrm{He}$ is referring to the term 'aluvión zoológico' (zoological invasion) used by the upper classes of Argentina in a derogatory way in reference to the massive immigration from rural areas (specially from northern provinces) to the city as a result of the industrialization which occurred in the country during Juan D. Perón's presidency (1945-55).

\section{References}

Alcina Franch, J. 1990. Indianismo e Indigenismo en América. Madrid: Alianza.

Angelo, D. 2005. La arqueología en Bolivia: reflexiones sobre la disciplina a inicios del Siglo XXI. Arqueología Suramericana, 1(2): 185-211.

Archenti, A., Sabarots, H. and Wallace, S. 1993. Raza y racismo. In Antropologia (ed. M. Lischetti). Buenos Aires: EUDEBA, pp. 211-36.

Arnold, B. 1990. The past as propaganda: totalitarian archaeology in Nazi Germany. Antiquity, 64(244): 464-78.

Barre, M. C. 1983. Ideologías indigenistas y movimientos indios. México: Siglo XXI.

Borgoño Alvarado, M. 2004. Notas sobre narración e ideología frente a la diversidad Latinoamericana. Revista de Antropología Experimental, 4: 2-17.

Califano, M., Pérez Diez, A. and Balzano, S. 1985. Etnología. In Evolución de las Ciencias en la República Argentina 1872-1972: Antropología, Vol. 10. Buenos Aires: Centro Argentino de Etnología Americana, Sociedad Científica Argentina, pp. 9-71.

Cresto, J. J. 2004. Roca y el mito del genocidio. La Nación (Argentina), 23 November, p. 17.

Curtoni, R., Lazzari, A. and Lazzari, M. 2003. Middle of nowhere: a place of war memories, commemoration, and aboriginal re-emergence (La Pampa, Argentina). World Archaeology, 35: 61-78.

Dawkins, R. 1985. El gen egoísta: Las bases biológicas de nuestra conducta. Barcelona: Salvat Editores, S.A.

Díaz-Andreu, M. 1993. Theory and ideology: Spanish archaeology under the Franco regime. Antiquity, 67: 74-82.

Funari, P. 1995. Mixed features of archaeological theory in Brazil. In Theory in World Archaeology: A World Perspective (ed. P. Ucko). London and New York: Routledge, pp. 236-50.

Funari, P. 1999. Maroon, race and gender: Palmares material culture and social relations in a runaway settlement. In Historical Archaeology: Back from the Edge (eds P. Funari, M. Hall and S. Jones). London: Routledge, pp. 308-27.

Gann, R. 2000. Post-modern perspectives on race and racism: help or hindrance? Paper given at the Political Studies Association 50th Annual Conference, London.

Gianotti, C. 2000. Monumentalidad, ceremonialismo y continuidad ritual. TAPA 19 Paisajes Culturales Sudamericanos: de las prácticas sociales a las representaciones: 87-102.

Gnecco, C. 2002. La indigenización de las Arqueologías Nacionales. Convergencia, 27: 133-49.

Gnecco, C. and Hernández, C. 2005. Stone statues, native histories and archaeologists in southwestern Colombia. Unpublished paper. 
González, A. R. 1953. La boleadora, su área de dispersión y tipos. Revista del Museo de la Universidad Eva Perón. Vol. 4. Buenos Aires: Sección Antropología, pp. 133-292.

Gosden, C. 2001. Postcolonial archaeology: issues of culture, identity and knowledge. In Archaeological Theory Today (ed. I. Hodder). Cambridge: Polity Press, pp. 241-61.

Grillo, R. D. 2003. Cultural essentialism and cultural anxiety. Anthropological Theory, 3(2): 157-73.

Hernando, A. 2004. Arqueología de la identidad: una alternativa estructuralista para la arqueología cognitiva. In Teoría arqueológica en América del Sur (eds G. Politis and R. Peretti). Serie Teórica 3, Olavarría: Facultad de Ciencias Sociales, UNCPBA, pp. 33-56.

Imbelloni, J. 1937. Fuéguidos y Láguidos: Posición actual de la raza Paleoamericana, o de Lagoa Santa. Anales del Museo Argentino de Ciencias Naturales, 39: 79-104.

Imbelloni, J. 1938. Tabla clasificatoria de los indios: regiones biológicas y grupos raciales humanos. Physis, 12: 229-49.

Imbelloni, J. 1942. Sobre craneología de los uru: supervivencias de razas australoides en los Andes. Actas XXVII Congreso Internacional de Americanistas, Lima: 3-22.

Iriarte, J., Holts, I., López, J. and Cabrera, L. 2001. Subtropical wetland adaptation in southeastern Uruguay: an archaeobotanical perspective. In Enduring Records: The Environmental and Cultural Heritage of Wetlands (ed. B. Purdy). Oxford: Berg, pp. 61-70.

Kellas, J. 1998. The Politics of Nationalism and Ethnicity. London: Macmillan.

Kohl, P. and Fawcett, C. 1995. Archaeology in the service of the state: theoretical considerations. In Nationalism, Politics, and the Practice of Archaeology (eds P. Kohl and C. Fawcett). Cambridge: Cambridge University Press, pp. 3-18.

Lander, E. 2003. Ciencias sociales: saberes coloniales y eurocéntricos. In La colonialidad del saber: eurocentrismo y ciencias sociales: Perspectivas latinoamericanas (ed. E. Lander). Buenos Aires: CLACSO, pp. 11-40.

Langebaek, C. 2003. Arqueología colombiana: ciencia, pasado y exclusión. Bogotá: Colciencias.

Lazzari, A. 2002. Indio argentino, cultura (nacional): Del Instituto Nacional de la Tradición al Instituto Nacional de Antropología. In Historia y estilos de trabajo de campo en Argentina (eds S. Visacovsky and R. Guber). Buenos Aires: Editorial Antropofagia, pp. 152-201.

López Mazz, J. 2004. Arqueología e identidad uruguaya: el saber y el poder en las vanguardias intelectuales. In Teoría arqueológica en América del Sur (eds G. Politis and R. Peretti), Serie Teórica 3. Olavarría: Facultad de Ciencias Sociales, UNCPBA, pp. 197-211.

Mamani Condori, C. 1996. History and prehistory in Bolivia: what about the Indians? In Contemporary Archaeology in Theory (eds R. Preucel and I. Hodder). Oxford: Blackwell, pp. 632-45.

Millones, L. 2004. Ser indio en el Perú: la fuerza del pasado: Las poblaciones indígenas del Perú (costa y sierra). Buenos Aires: Siglo XXI de Argentina editores.

Moreno Sandoval, A. 1998. El indio: entre el racismo, la nación y la nacionalidad colombiana. 1er Congreso Virtual de Antropología y Arqueología, Equipo NayA. Available at: http://www.naya. org.ar/congreso.

Oliveira, V. and Oliveira Jorge, S. 1995. Theoretical underpinnings of Portuguese archaeology in the twentieth century. In Theory in World Archaeology: A World Perspective (ed. P. Ucko). London and New York: Routledge, pp. 251-62.

Palavecino, E. 1965. Introducción al problema indígena Chaqueño. Primera Convención Nacional de Antropología (II Parte). Chaco: Facultad de Humanidades, UNNE.

Palavecino, E. 1977 [1948]. Areas y capas culturales en el territorio Argentino: Museo de Historia Natural de San Rafael, Mendoza, Argentina. Notas del Museo, 18: 3-82. 
Pi Ugarte, R. 1993. Los indios del Uruguay. Montevideo: Banda Oriental.

Podgorny, I. and Politis, G. 1992. Que sucedió en la historia? Los esqueletos araucanos del Museo de La Plata y la conquista del desierto. Arqueología Contemporánea, 3: 73-9.

Politis, G. 1992. Arqueología en América Latina Hoy. Colombia: Biblioteca Banco Popular.

Politis, G. 1995. The socio-politics of the development of archaeology in Hispanic South America. In Theory in Archaeology: A World Perspective (ed. P. Ucko). London: Routledge, pp. 197-235.

Politis, G. 2003. The theoretical landscape and the methodological developments of archaeology in Latin America. American Antiquity, 68(2): 247-72.

Quijano, A. 2003. Colonialidad del poder, eurocentrismo y América Latina. In La colonialidad del saber: eurocentrismo y ciencias sociales: Perspectivas latinoamericanas (ed. E. Lander). Buenos Aires: CLACSO, pp. 201-46.

Ramos, A. 1997. From Eden to limbo: the construction of indigenism in Brazil. In Social Construction of the Past: Representation as Power (eds G. Bond and A. Gilliam). London and New York: Routledge, pp. 74-88.

Schmitz, P. 1976. Sitios de pesca lacustre en Río Grande do Sul. Porto Alegre, Brasil: Pontificia Universidade Católica de Porto Alegre.

Shanks, M. and Tilley, C. 1987. Social Theory and Archaeology. Cambridge: Polity Press.

Shepherd, N. 2003. When the hand that holds the trowel is black ...': disciplinary practices of selfrepresentation and the issue of 'native' labour in archaeology. Journal of Social Archaeology, 3(2): $334-52$.

Silberman, N. 1995. Promised land and chosen peoples: the politics and poetics of archaeological narrative. In Nationalism, Politics, and the Practice of Archaeology (eds P. Kohl and C. Fawcett). Cambridge: Cambridge University Press, pp. 249-62.

Steward, J. 1949. South American cultures: an interpretative summary. In Handbook of South American Indians (ed. J. Steward). Washington, DC: Smithsonian Institution Bureau of American Ethnology, pp. 669-772.

Stocking, G. 1968. Race, Culture and Evolution: Essays in the History of Anthropology. New York: The Free Press.

Taddei, A. 1981. Algunos aspectos de la arqueología del Uruguay: investigaciones paleoindias al sur de la línea ecuatorial. Estudios Atacameños, 8: 62-93.

Torre Wilson, J. 1996. Carta al director. El Observador (Montevideo), 30 January, p. 22.

Trigger, B. 1989. A History of Archaeological Thought. Cambridge: Cambridge University Press.

Verdecio, G. 1996. La invención del Uruguay. Montevideo: Graffiti.

Vidart, D. 1996. Los cerritos de indios del este de Uruguay. Montevideo: Banda Oriental.

Vignati, A. 1931. Investigaciones antropológicas en el litoral marítimo sudatlántico bonaerense. Notas Preliminares del Museo de La Plata, 1(2): 1-19.

Vignati, A. 1953. Materiales para la arqueología de la Patagonia. Aporte I. Anales del Museo de La Plata n.s. Antropología, 3: 5-38.

Vignati, A. 1957-59. El hombre fósil de Mata Molle. Notas del Museo de La Plata, 19: 327-51.

Vignati, A. 1960. El indigenado de la Provincia de Buenos Aries. Anales de la Comisión de Investigaciones Cientificas de la Provincia de Buenos Aires, 1: 95-182.

Wade, P. 1997. Representation and power: blacks in Colombia. In Social Construction of the Past: Representation as Power (eds G. Bond and A. Gilliam). London and New York: Routledge, pp. 59-73.

Wade, P. 2004. Human nature and race. Anthropological Theory, 4(2): 157-72. 
Willey Gordon, R. 1971. An Introduction to American Archaeology, Vol. 2, South America. Englewood Cliffs, NJ: Prentice-Hall.

Young, R. J. 1996. Colonial Desire: Hybridity in Theory, Culture and Race. London and New York: Routledge.

Zimmerman, L. 2000. A new and different archaeology? With a postscript on the impact of the Kennewick dispute. In Repatriation Reader: Who Owns American Indian Remains? (ed. D. Mihesuah). Lincoln, NB: University of Nebraska Press, pp. 294-306.

Rafael Pedro Curtoni, archaeologist, MA in arts (Institute of Archaeology, University College of London 1999), is currently finishing a PhD at Universidad Nacional de La Plata, Argentina and teaching at Universidad Nacional del Centro de la Provincia de Buenos Aires.

Gustavo G. Politis, archaeologist, PhD (Universidad Nacional de La Plata, Argentina 1984), is currently a researcher for the National Research Council of Argentina and Professor at Universidad Nacional del Centro de la Provincia de Buenos Aires and Universidad Nacional de La Plata, Argentina. 